\title{
STUDI PENGELOLAAN INFRASTRUKTUR DASAR DI KECAMATAN TELOK BATANG KABUPATEN KAYONG UTARA Studi Kasus: Desa Sungai Paduan Dan Desa Mas Bangun
}

\author{
Heri Azwansyah ${ }^{1}$; Ferry Juniardi ${ }^{2}$ \\ ${ }^{1}$ Staf Pengajar Program Studi Teknik Sipil, Universitas Tanjungpura, Indonesia \\ ${ }^{2}$ Staf Pengajar Program Studi Teknik Sipil, Universitas Tanjungpura, Indonesia \\ Email : heriazwansyah@gmail.com
}

\begin{abstract}
ABSTRAK
Infrastruktur yang memadai dapat mendukung kegiatan ekonomi masyarakat. Studi ini bertujuan untuk mengetahui aksesibilitas infrastruktur dasar bagi masyarakat pedesaan di Desa Sungai Paduan dan Desa Mas Bangun Kecamatan Telok Batang. Studi ini membutuhkan data-data aksesibilitas dan kondisi infrastruktur dasar yang diperoleh dari instansi terkait, observasi lapangan dan interview. Studi ini menggunakan metode Integrated Rural Accessibility Planning (IRAP). Tingkat aksesibilitas menggunakan beberapa indikator aksesibilitas tiap infastruktur. Hasil penelitian menyimpulkan bahwa pada Desa Sungai Paduan prioritas pertama, kedua dan ketiga berturut-turut sektor pertanian/perkebunan, sektor sumber air bersih, dan sektor industri/perdagangan dengan nilai aksesibilitas sebesar 9,90, 9,00, dan 7,59. Pada Desa Mas Bangun, prioritas pertama, kedua dan ketiga untuk mendapat penanganan infrastruktur adalah sektor pertanian/perkebunan, sektor sumber air bersih, dan sektor Kesehatan dengan nilai aksesibilitas sebesar 10,80, 9,00, dan 7,62. Untuk meningkatkan aksesibilitas inftasratruktur tersebut dapat dilakukan dengan perbaikan fasilitas dan penyedian sarana transportasi, sementara saat ini jalan desa yang ada masih baik.
\end{abstract}

Kata kunci: infrastruktur dasar, nilai aksesibilitas

\begin{abstract}
A decent infrastructure is able to support economic activities. This study aims to find out the basic infrastructure accessibility for rural communities in Sungai Paduan village and Mas Bangun village, Telok Batang district. This study requires the data of access and basic infrastructure conditions, obtained from the relevant agencies/departments, field observation, and inteview. This study use Integrated Rural Accessibility Planning (IRAP) method. A level of accessibility uses some indicators of accessibility in each of infrastructures. The study concluded that the priorities in Sungai Paduan village serially are: agriculture/plantation as the first priority, followed by water resource sector and the industrial/trade sector, with accessibility values ranging from 9.90, 9.00, and 7.59. While in Mas Bangun village, as the first, second and the third priority to get infrastructure treatment are agriculture/plantation, water resources sector, and the health sector with the accessibility values ranging from $10.80,9.00$, and 7.62. To improve the accessibility of infrastructure can be done through facility repairing and the provision of means of transportation. Currently, the existing roads in both villages are in the good condition.
\end{abstract}

Keywords: basic infrastructure, accessibility values

\section{Pendahuluan}

Infrastruktur di setiap negara merupakan hal yang sangat penting guna meningkatkan kesejahteraan rakyat, begitu pula di Indonesia (KPPOD, 2012). Ketersediaan infrastruktur yang memadai akan sangat membantu berkembangnya masyarakat di suatu wilayah, kegiatan usaha, ekonomi dan sosial di suatu wilayah semakin berkembang seiring dengan semakin baiknya ketersediaan infrastruktur.
Pentingnya ketersediaan infrastruktur dasar tersebut membuat Pemerintah sebagai pihak yang berwenang untuk menyediakan infrastruktur tersebut membutuhkan suatu dana yang sangat besar untuk mendanai pembangunan infrastruktur yang menyeluruh dan berkesinambungan. Ironisnya, bahwa kemampuan pemerintah untuk menyediakan dana untuk menyediakan infrastruktur jauh dari kata cukup

Ketersediaan infrastruktur memiliki 
Azwansyah dan Juniardi. "Studi Pengelolaan Infrastruktur Dasar di Kec. Telok Batang"

keterkaitan yang sangat kuat dengan tingkat pertumbuhan ekonomi dan kesejahteraan masyarakat. Hal tersebut dapat dilihat dari kenyataan bahwa daerah yang mempunyai kelengkapan sistem infrastruktur yang lebih baik, mempunyai tingkat laju pertumbuhan ekonomi dan kesejahteraan masyarakat yang lebih baik pula, dibandingkan dengan daerah yang mempunyai kelengkapan infrastruktur yang terbatas. Dengan demikian dapat dikatakan bahwa penyediaan infrastruktur merupakan faktor kunci dalam mendukung setiap kegiatan pembangunan termasuk dalam mendukung pembangunan kawasan perbatasan.

Pembangunan infrastruktur desa harus dapat meingkatkan martabat hidup (human well being) orang desa. Pemahaman terhadap martabat hidup orang desa dalam pengertian material, sebagaimana tercermin dalam wacana sandang, pangan dan papan sangat keliru dan dangkal. Pendekatan tersebut kurang membumi pada konteks lokal serta mengabaikan potensi (kekuatan) yang tersimpan dalam kehidupan desa. Gagasan pemberdayaan masyarakat merupakan upaya membangkitkan kekuatan dan potensi masyarakat yang bertumpu pada komunitas lokal melalui pendekatan partisipatif dan belajar bersama.

Kegiatan merencanakan dan membangun infrastruktur pedesaan berbasis pemberdayaan masyarakat dapat meningkatkan kesempatan kerja dan berusaha masyarakat di daerah pedesaan, serta dapat meningkatkan komitmen masyarakat terhadap keberlangsungan infrastruktur pedesaan yang dibangunnya, dengan demikian infrastruktur pedesaan tersebut akan lebih terpelihara dan manfaatnya dapat dirasakan masyarakat sendiri dalam jangka waktu yang lebih lama. Pengadaan infrastruktur pedesaan yang melibatkan masyarakat sangat tepat karena pada dasarnya teknologi yang digunakan pada pembangunan infrastruktur pedesaan secara umum bersifat sederhana dan masih dalam jangkauan kemampuan masyarakat desa.

Berdasarkan uraian diatas, maka diangkat suatu kajian yaitu 'Strategi Pengelolaan Infrastruktur Dasar Kecamatan Telok Batang Kabupaten Kayong Utara Studi Kasus Desa Sungai Paduan dan Desa Mas Bangun. Penelitian ini diharapkan menjadi arah dan pedoman dalam mengelola infrastruktur dalam rangka menjawab kebutuhan riil masyarakat guna mendorong pembangunan wilayah.

\section{Aksesibilitas Pedesaan}

Akses pedesaan, menurut Donnges (1999) dapat didefinisikan sebagai kemampuan, tingkat kesulitan penduduk desa untuk menggunakan, mencapai atau mendapatkan barang dan jasa yang diperlukannya. Aksesibilitas mempunyai tiga unsur, yaitu lokasi rumah tangga / pemukiman, lokasi fasilitas/ jasa, serta sistem transportasi yang menghubungkan keduanya (Dennis, 1998).

Akses penduduk pedesaan dapat dikelompokkan menjadi tiga kategori umum (Donnges, 1999) : (1) Akses yang berhubungan dengan kebutuhan pokok seperti penyediaan air dan sumber energi, (2) Akses yang berhubungan dengan aspek kesejahteraan sosial di pedesaan seperti kesehatan dan pendidikan, (3) Akses yang berhubungan dengan aspek kesejahteraan ekonomi di pedesaan seperti pertanian, perkebunan, peternakan, industri kecil dan lain-lain.

\section{Akses Terhadap Sumber Air}

Air merupakan kebutuhan dasar dan harus tersedia sepanjang tahun. Sumber air bersih mudah didapat adalah salah satu tujuan pembangunan. Menurut Parikesit dkk (2003) informasi yang diperlukan untuk mengidentifikasi zona prioritas dilakukan perbaikan akses terhadap sumber air adalah: (a) jumlah penduduk zona tertentu, (b) jenis sumber air yang tersedia, (c) jumlah rumah tangga pengguna sumber air, (d) jarak ke sumber air, (e) waktu pengambilan air, (f) kualitas sumber air, dan (g) persepsi masyarakat tentang permasalahan dan prioritas.

\section{Akses Terhadap Kelistrikan}

Sumber tenaga listrik merupakan sarana yang dapat memperlancar aktifitas penduduk. Menurut Parikesit dkk (2003), informasi yang diperlukan untuk mengidentifikasi zona prioritas dilakukan perbaikan akses terhadap Sumber Tenaga Listrik adalah : (a) jumlah listrik yang dialiri, (b) prasarana dan sarana menuju objek sumber tenaga listrik, (c) jarak menuju sumber tenaga listrik, (d) waktu menuju sumber tenaga listrik, (e) biaya yang 
Azwansyah dan Juniardi. "Studi Pengelolaan Infrastruktur Dasar di Kec. Telok Batang"

diperlukan menuju sumber tenaga listrik, dan (f) persepsi masyarakat tentang permasalahan dan prioritas.

\section{Akses Terhadap Pendidikan Dasar}

Pendidikan adalah kebutuhan dasar di zaman modern. Sebagian besar penduduk desa sudah beranggapan pentingnya pendidikan bagi anak-anaknya dan demi perkembangan dimasa depan. Menurut Parikesit dkk (2003) informasi yang diperlukan untuk mengidentifikasi zona prioritas dilakukan perbaikan akses terhadap pendidikan dasar adalah : (a) jumlah penduduk zona tertentu, (b) keberadaan sekolah, (c) jarak ke sekolah, (d) waktu perjalanan ke sekolah, (e) biaya perjalanan menuju sekolah, dan (f) persepsi masyarakat tentang permasalahan dan prioritas.

\section{Akses Terhadap Fasilitas Kesehatan}

Sistem pelayanan kesehatan terhadap ibu, anak dan masyarakat merupakan faktor penting yang mempengaruhi tingkat kesehatan. Menurut Parikesit dkk (2003) informasi yang diperlukan untuk mengidentifikasi zona prioritas dilakukan perbaikan akses terhadap fasilitas kesehatan adalah : (a) jumlah penduduk zona tertentu, (b) keberadaan fasilitas pelayanan kesehatan, (c) jenis fasilitas pelayanan kesehatan, (d) petugas pelayanan kesehatan, (e) jumlah petugas pelayanan kesehatan, (f) prasarana transportasi menuju pusat pelayanan kesehatan, (g) sarana transportasi menuju pusat pelayanan kesehatan, (h) jarak ke pusat pelayanan kesehatan, (i) waktu menuju pusat pelayanan kesehatan, (j) biaya perjalanan menuju sekolah, dan $(k)$ persepsi masyarakat tentang permasalahan dan prioritas.

\section{Akses Terhadap Pertanian/ Perkebunan/Peternakan}

Sebagian besar penduduk pedesaan bekerja sebagai petani/pekebun/peternak. Hasil produk tersebut dapat dikonsumsi sendiri dan dapat pula dipasarkan. Parikesit dkk (2003) menjelaskan bahwa informasi yang diperlukan untuk mengidentifikasi zona prioritas dilakukan perbaikan akses terhadap produksi pertanian/perkebunan/ peternakan adalah : (a) jumlah rumah tangga petani/pekebun, (b) jumlah hasil produksi pertanian/ perkebunan yang dijual, (c) prasarana transportasi menuju lahan pertanian/perkebunan, (d) sarana transportasi menuju lahan pertanian/perkebunan, (e) jarak ke tempat penjualan produk-produk pertanian/ perkebunan, (f) waktu perjalanan menuju tempat penjualan produk-produk pertanian/perkebunan, (g) biaya perjalanan menuju tempat penjualan produk-produk pertanian/perkebunan/peternakan, dan (h) persepsi masyarakat tentang permasalahan dan prioritas.

\section{Integrated Rural Accessibility Planning (IRAP)}

IRAP adalah prosedur perencanaan yang mampu menjawab kebutuhan riil penduduk pedesaan (Parikesit dkk, 2003), serta merupakan pelengkap bagi prosedur perencanaan konvensional. IRAP berkembang dari suatu pemahaman mengenai kebutuhan akses penduduk pedesaan dan mencakup berbagai sektor antara lain : pusat-pusat pemerintahan, transportasi, air bersih, energi, pendidikan, kesehatan, dan perekonomian.

IRAP merupakan metode perencanan yang melibatkan partisipasi masyarakat, atau kata lain IRAP merupakan metode perencanaan yang berbasis pemberdayaan masyarakat (Parikesit dkk, 2003). Keberhasilan metode perencanaan ini sangat ditentukan oleh peran aktif masyarakat dalam memberikan informasi dan aspirasi sesuai kebutuhan riil masyarakat.

IRAP merupakan proses perencanaan tingkat lokal yang didasarkan pada konsep bahwa salah satu kendala utama pembangunan adalah kekurangan akses penduduk. Metodologi yang diguanakan IRAP dikatakan terintegrasi, karena mempertimbangkan semua kemungkinan intervensi untuk memperbaiki akses. Proses penentuan prioritas pada sektorsektor yang tercakup pada proses IRAP dilakukan dengan menggunakan alat sederhana berupa indikator manfaat. Indikator manfaat merupakan fungsi dari : (1) potensi bebagai sektor ,dan (2) waktu dan upaya yang dibutuhkan untuk mencapai lokasi barang dan jasa tertentu. Semakin banyak penduduk yang kekurangan akses dan semakin jauh jarak yang harus ditempuh, maka semakin tinggi angka indikator aksesibilitas. 
Azwansyah dan Juniardi. "Studi Pengelolaan Infrastruktur Dasar di Kec. Telok Batang"

Penentuan tingkat aksesibilitas menggunakan basis beberapa indikator aksesibilitas. Indikator aksesibilitas adalah indikator tingkat kesulitan untuk mencapai pelayanan kebutuhan barang dan jasa. Indikator aksesibilitas merupakan sarana perencanaan pertama yang memberikan indikasi sederhana kebutuhan transportasi penduduk suatu daerah. Profil aksesibilitas menyediakan sebuah ringkasan (rekapitulasi) dan penilaian kondisi akses di daerah penelitian. Peta aksesibilitas digunakan untuk berbagai keperluan dan dapat menunjukkan infrastruktur transportasi, distribusi pelayanan dan fasilitas serta daerah pelayanannya. Azwansyah (2010) menyatakan bahwa nilai nilai aksesibilitas (NA) diperoleh dari penjumlah dari hasil pengalian nilai indikator ( $\mathrm{NI})$ dengan bobot indikator (BI), dengan bentuk formula sebagai berikut :

$\mathrm{NA}=\sum_{i=1}^{n} \mathrm{NI} \times \mathrm{BI}$

\section{Hasil dan Pembahasan}

Kecamatan Teluk Batang Kabupaten Kayong Utara merupakan kecamatan yang memiliki jumlah penduduk yang relatif besar dengan jumlah penduduk tahun 2011 sebesar 19.380 jiwa dengan kepadatan penduduk 30 orang $/ \mathrm{km}^{2}$ (BPS Kabupaten Kayong Utara, 2012). Berdasarkan data yang diperoleh dari kuisioner dan dari hasil observasi lapangan, diketahui bahwa mayoritas penduduk pada tiap desa adalah petani/nelayan. Dan rata-rata luas tanah yang ada di Kecamatan Teluk Batang Kabupaten Kayong Utara digunakan sebagai tanah pertanian/ perkebunan dan perikanan sehingga sebagian penduduk bergantung pada hasil pertanian/ perkebunan dan perikanan.

\section{Kondisi Sistem Transportasi Pedesaan}

Sarana perhubungan yang ada pada Kecamatan Teluk Batang Kabupaten Kayong Utara adalah transportasi darat dan air. Tetapi yang lebih mendominasi adalah jalan darat. Jaringan jalan yang ada meliputi jalan aspal, jalan tanah dan jalan beton. Namun hampir di tiap desa termasuk Desa Sungai Panduan dan Desa Mas Bangun infrastruktur jalannya sangat jelek, dan hal tersebut merupakan salah satu kendala yang tampak jelas bahwa akses untuk mencapai, menggunakan atau mendapatkan barang dan jasa yang diperlukan cukup sulit.

Sarana transportasi darat yang ada adalah mobil, sepeda motor dan sepeda sedangkan sarana transportasi air / sungai yang ada yaitu speedboat, motor air dan sampan. Selain itu air sungai tersebut merupakan salah satu sumber air yang digunakan penduduk desa dalam memenuhi kebutuhan hidup.

\section{Analisis Aksesibilitas}

Analisis nilai aksesibilitas dalam studi ini bertujuan untuk menentukan sektor dan desa prioritas untuk mendapat penanganan masalah aksesibilitasnya. Metode yang digunakan untuk menganalisa data adalah metode Integrated Rural Accessibility Planning ( IRAP ). Komponen yang diperlukan dalam analisa ini adalah indikator aksesibilitas yang terdiri dari nilai indikator dan bobot indikator setiap sub sektor dari masing - masing sektor yang diteliti dilanjutkan dengan penentuan nilai aksesibilitas untuk setiap desa dan sektor aksesibilitas yang ditinjau. Dalam analisa ini akan terlihat sektor dan desa yang menjadi prioritas untuk mendapat penanganan terhadap masalah aksesibilitasnya.

Untuk menentukan prioritas peningkatan aksesibilitas di tingkat desa, dilakukan perhitungan nilai aksesibilitas untuk tiap - tiap sektor yang ditinjau antara lain: sumber air, pendidikan, kesehatan, pertanian/perkebunan, perkantoran, industri/perdagangan, pemukiman, sumber tenaga listrik, dan perikanan.

Konsep yang diterapkan pada penelitian ini adalah aksesibilitas merupakan tingkat kesulitan. Hal ini berarti nilai aksesibilitas berbanding lurus dengan nilai indikator dan bobot indikator, maka semakin besar nilai indikator maupun bobot indikator berarti semakin besar pula nilai aksesibilitasnya dan berarti semakin sulit penduduk untuk memenuhi kebutuhannya. Hal ini berarti pul semakin besar nilai aksesibilitas maka semakin diprioritaskan untuk mendapatkan peningkatan aksesibilitas.

\section{Identifikasi Sektor Prioritas}

Untuk menentukan sektor-sektor dan masalah prioritas, maka dilakukan perhitungan dengan menggunakan metode IRAP. Analisa perhitungan nilai aksesibilitas 
Azwansyah dan Juniardi. "Studi Pengelolaan Infrastruktur Dasar di Kec. Telok Batang" berdasarkan formula yang dijelaskan Paduan dan Sungai Mas Bangun dapat sebelumnya.

Hasil analisis aksesibilitas untuk masing-masing sektor pada Desa Sungai

dilihat masing-masing pada Tabel 1 dan Tabel 2.

Tabel 1. Rekapitulas Nilai Aksesiblilitas Tiap Infrastruktur di Desa Sungai Paduan

\begin{tabular}{|c|l|c|}
\hline No & \multicolumn{1}{|c|}{ Sektor Yang Ditinjau } & Nilai Aksesibilitas \\
\hline 1 & Sektor Sumber Air Bersih & 9,00 \\
\hline 2 & Sektor Pertanian/Perkebunan & 9,90 \\
\hline 3 & Sektor Pendidikan & 5,25 \\
\hline 4 & Sektor Kesehatan & 7,46 \\
\hline 5 & Sektor Pemukiman & 5,44 \\
\hline 6 & Sektor Industri/Perdagangan & 7,59 \\
\hline 7 & Sektor Perkantoran & 4,83 \\
\hline 8 & Sektor Sumber Tenaga Listrik & 6,05 \\
\hline 9 & Sektor Perikanan & 7,00 \\
\hline
\end{tabular}

(Sumber : Analisis data, 2012)

Pada tabel Tabel 1 memperlihatkan nilai aksesibilitas masing-masing sektor di Desa Sungai Paduan. Nilai aksesibilitas tertinggi terdapat pada sektor pertanian/perkebunan dengan nilai aksesibilitas sebesar 9,90, diikuti urutan di bawah sektor sumber air bersih dengan nilai aksesibilitas sebesar 9,00 dan urtan ketiga pada sektor industri/ perdagangan dengan nilai aksesibilitas sebesar 7,59. Sementara nilai aksesibilitas terendaha pada sektor perkantoran dengan nilai aksesibilitas sebesar 4,83.

Berdasarkan nilai aksesibilitas tersebut mengandung arti bahwa di Desa Sungai Paduan yang menjadi sektor prioritas utama kebutuhan infrastruktur adalah di sektor pertanian/perkebunan karena selain sektor perikanan memang penduduk daerah ini juga relatif besar hidup dari sektor pertanian dan perkebunan dan sektor ini dirasakan masyarakat memiliki tingkat aksesibilitas yang relatif sulit sehingga menjadi prioritas utama. Selanjutnya sumber air bersih menempati prioritas kedua dan prioritas ketiga pada indsutri /perdangan. Sementara perkantoran tidak menjadi prioritas karena memang daerah ini merupakan daerah pedesaan tentunya kebutuhan akan kantorkantor pelayanan bagi masyarakat belum dianggap sebagai hal yang penting.

Tabel 2. Rekapitulasi Nilai Aksesiblilitas Tiap Infrastruktur di Desa Mas Bangun

\begin{tabular}{|c|l|c|}
\hline No & \multicolumn{1}{|c|}{ Sektor Yang Ditinjau } & Nilai Aksesibilitas \\
\hline 1 & Sektor Sumber Air Bersih & 9,00 \\
\hline 2 & Sektor Pertanian/Perkebunan & 10,80 \\
\hline 3 & Sektor Pendidikan & 5,45 \\
\hline 4 & Sektor Kesehatan & 7,63 \\
\hline 5 & Sektor Pemukiman & 5,44 \\
\hline 6 & Sektor Industri/Perdagangan & 6,23 \\
\hline 7 & Sektor Perkantoran & 4,83 \\
\hline 8 & Sektor Sumber Tenaga Listrik & 6,78 \\
\hline 9 & Sektor Perikanan & 7,45 \\
\hline
\end{tabular}

(Sumber : Analisis data, 2012)

Pada tabel Tabel 2 memperlihatkan nilai aksesibilitas masing-masing sektor di Desa Mas Bangun. Nilai aksesibilitas tertinggi terdapat pada sektor pertanian/perkebunan dengan nilai aksesibilitas sebesar 10,80, diikuti urutan di bawah sektor sumber air bersih dengan nilai aksesibilitas sebesar 9,00 dan urtan ketiga pada sektor kesehatan dengan nilai aksesibilitas sebesar 7,63. Sementara nilai aksesibilitas terendaha pada sektor perkantoran dengan nilai aksesibilitas sebesar 4,83.

Berdasarkan nilai aksesibilitas tersebut mengandung arti bahwa di Desa Mas Bangun yang menjadi sektor prioritas utama kebutuhan infrastruktur adalah di sektor pertanian/perkebunan karena selain sektor perikanan memang penduduk daerah ini juga relatif besar hidup dari 
Azwansyah dan Juniardi. "Studi Pengelolaan Infrastruktur Dasar di Kec. Telok Batang"

sektor pertanian dan perkebunan dan sektor ini dirasakan masyarakat memiliki tingkat aksesibilitas yang relatif sulit sehingga menjadi prioritas utama. Selanjutnya sumber air bersih menempati prioritas kedua dan prioritas ketiga pada sektor kesehatan. Sementara perkantoran tidak menjadi prioritas karena memang daerah ini merupakan daerah pedesaan tentunya kebutuhan akan kantor-kantor pelayanan bagi masyarakat belum dianggap sebagai hal yang penting.

Sebagaimana dijelaskan sebelumnya bahwa penanganan perbaikan infrastruktur dapat dilakukan melalui dua cara yaitu (1) perbaikan di bidang transportasinya dan (2) perbaikan bukan di bidang transportasinya.

Penanganan infratsruktur di bidang transportasi dilakukan dengan perbaikan prasarana transportasi diantaranya jaringan jalan desa, dan perbaikan/penyediaan sarana transportasi diantaranya penyediaan angkutan umum. Sementara itu, perbaikan bukan di bidang transportasinya dilakukan dengan perbaikan / pembangunan prasarana transportasi dasar tersebut atau fasilitasnya. Untuk menentukan menentukan penangan yang dilakukan, maka berdasarkan penjelasan di atas dilakukan perbandingan nilai aksesibilitas antara indikator aksesibilitas, prasarana dan sarana transporrtasi. Hasil analisis nilai aksesibilitas untuk indikator fasilitas, prasarana dan sarana transportasi dapat dilihat pada Tabel 3.

Tabel 3. Perbandingan Nilai Aksesibilitas Indikator Fasilitas, Prasarana Dan Sarana Transportasi di Desa Sungai Paduan

\begin{tabular}{|c|l|c|c|c|}
\hline \multirow{2}{*}{ No } & \multirow{2}{*}{ Sektor Aksesibilitas } & \multicolumn{3}{|c|}{ Nilai Aksesibilitas } \\
\cline { 3 - 5 } & & Fasilitas & Prasarana & Sarana \\
\hline 1 & Sektor Sumber Air Bersih & 15,50 & 5,50 & 10,00 \\
\hline 2 & Sektor Pertanian/Perkebunan & 18,00 & 5,00 & 9,00 \\
\hline 3 & Sektor Pendidikan & 0,00 & 5,00 & 12,50 \\
\hline 4 & Sektor Kesehatan & 0,00 & 4,00 & 7,00 \\
\hline 5 & Sektor Pemukiman & 0,00 & 5,00 & 8,00 \\
\hline 6 & Sektor Industri/Perdagangan & 16,00 & 4,00 & 4,50 \\
\hline 7 & Sektor Perkantoran & 0,00 & 3,00 & 9,50 \\
\hline 8 & Sektor Sumber Tenaga Listrik & 8,00 & 4,00 & 6,00 \\
\hline 9 & Sektor Perikanan & 16,00 & 6,00 & 9,00 \\
\hline
\end{tabular}

(Sumber : Analisis data, 2012)

Pada Tabel 3 menampilkan peerbandingan nilai aksesibilitas indikator fasilitas, prasarana dan sarana transportas di Desa Sungai Paduan. Untuk Desa Sungai Paduan pada sektor sumber air bersih, sektor pertanian dan perkebunan, sektor industri/perdagangan, sektor sumber tenaga listrik, dan sektor perikanan mendapat prioritas utama pada fasilitasnya, dengan nilai aksesibilatasnya masingmasing sektor yaitu pada sektor sumber air bersih sebesar 15,50, sektor pertanian dan perkebunan sebesar 18,00, sektor industri/perdagangan sebesar 16,00, sektor sumber tenaga listrik dengan nilai aksesibilitas sebesar 8,00, dan sektor perikanan sebesar 16,00. Peningkatan aksesibilitas ini akan dilakukan dengan pendekatan intervensi, yaitu pada sektor sumber air bersih, pendekatan intervensinya adalah dengan membangun penampungan air hujan yang bisa menyuplai ke semua desa. Sektor pertanian dan perkebunan, intervensinya dilakukan dengan membangun tempat penjualan dan pemasaran hasil produksi pertanian dan perkebunan. Sektor industri/ perdagangan, pendekatan intervensinya yang dilakukan adalah membangun tempat pelatihan bagi usaha kecil menengah. Sektor sumber tenaga listrik, pendekatan intervensinya yang dilakukan adalah dengan memasang jaringan listrik yang belum dialiri. Sementara pada sektor perikanan, pendekatan intervensinya yang dilakukan adalah dengan membangun pasar tempat menjual hasil penangkapan ikan.

Indikator prasarana transportasi tidak mendapatkan prioritas utama, hal ini 
Azwansyah dan Juniardi. "Studi Pengelolaan Infrastruktur Dasar di Kec. Telok Batang"

dikarenakan jaringan jalan di Desa Sungai

Paduan sudah bagus, sehingga saat ini belum memerlukan penanganan lagi.

Nilai aksesibilitas indikator sarana transportasi di Desa Sungai Paduan juga menjadi prioritas utama, sektor yang menjadi prioritas nya yaitu sektor pendidikan dengan nilai aksesibilitasnya sebesar 12,50, sektor kesehatan dengan nilai aksesibilitasnya sebesar 7,00, sektor pemukiman dengan nilai aksesibilitasnya sebesar 8,00, dan sektor perkantoran dengan nilai aksesibilitasnya sebesar 9,50.

Pendekatan intervensinya secara keseluruhan adalah sama, yaitu dengan melakukan perbaikan sarana transportasi menuju tempat pelayan dan pengadaan sarana angkutan umum yang dapat menunjang aktivitas penduduk, hal ini dimaksudkan untuk mempermudah mobilitas pergerakan lebih cepat, mudah, dan nyaman.

Tabel 4. Perbandingan Nilai Aksesibilitas Indikator Fasilitas, Prasarana Dan Sarana Transportasi di Desa Mas Bangun

\begin{tabular}{|c|l|c|c|c|}
\hline \multirow{2}{*}{ No } & \multicolumn{1}{|}{ Sektor Aksesibilitas } & \multicolumn{3}{|c|}{ Nilai Aksesibilitas } \\
\cline { 3 - 5 } & & Fasilitas & Prasarana & Sarana \\
\hline 1 & Sektor Sumber Air Bersih & 15,50 & 5,50 & 10,00 \\
\hline 2 & Sektor Pertanian/Perkebunan & 18,00 & 5,00 & 15,00 \\
\hline 3 & Sektor Pendidikan & 0,00 & 5,00 & 12,50 \\
\hline 4 & Sektor Kesehatan & 0,00 & 4,00 & 7,00 \\
\hline 5 & Sektor Pemukiman & 0,00 & 5,00 & 8,00 \\
\hline 6 & Sektor Industri/Perdagangan & 4,00 & 4,00 & 4,50 \\
\hline 7 & Sektor Perkantoran & 0,00 & 3,00 & 9,50 \\
\hline 8 & Sektor Sumber Tenaga Listrik & 8,00 & 4,00 & 6,00 \\
\hline 9 & Sektor Perikanan & 16,00 & 10,50 & 9,00 \\
\hline
\end{tabular}

(Sumber : Analisis data, 2012)

Pada Tabel 4 menampilkan perbandingan nilai aksesibilitas indikator fasilitas, prasarana dan sarana transportas di Desa Mas Bangun. Sektor sumber air bersih, sektor pertanian/perkebunan, sektor sumber tenaga listrik dan sektor perikanan mendapatkan prioritas utama pada indikator fasilitas. Masing-masing nilai aksesibilitas dan intervensinya yaitu, sektor sumber air bersih nilai aksesibilitasnya sebesar 15,50 dengan intervensinya yaitu pembangunan jaringan PDAM yang bisa di suplai ke semua penduduk desa, sektor pertanian/perkebunan nilai aksesibilitasnya sebesar 18,00 dengan intervensinya yaitu membangun tempat penjualan hasil produksi, Sektor sumber tenaga listrik nilai aksesibilitasnya sebesar 8,00 dengan intervensinya yaitu pemasangan jaringan yang belum di aliri listrik, dan untuk sektor perikanan nilai aksesibilitasnya sebesar 16,00 dengan intervensinya yaitu membangun tempat penjualan dan pemasaran hasil perikanan.

Pada Desa Mas Bangun indikator prasarana transportasi tidak menjadi prioritas utama, hal ini dikarenakan jaringan jalan di desa ini sudah bagus, sehingga saat ini belum memerlukan penanganan lagi.

Sektor pendidikan, sektor kesehatan, sektor pemukiman, sektor industri/ perdagangan, dan sektor perkantoran di Desa Mas bangun mendapat prioritas utama pada sarana transportasinya, dengan nilai aksesibilitasnya masingmasing sektor yaitu pada sektor pendidikan sebesar 12,50, sektor kesehatan sebesar 7,00 , sektor pemukiman sebesar 8,00, sektor sumber industri/perdagangan sebesar 4,50, dan sektor perkantoran sebesar 9,50.

Pendekatan intervensinya sacara keseluruhan adalah sama, yaitu dengan melakukan perbaikan sarana transportasi menuju tempat pelayanan dan pengadaan sarana angkutan umum yang dapat menunjang aktivitas penduduk, hal ini dimaksudkan untuk mempermudah mobilitas pergerakan lebih cepat, mudah, dan nyaman.

\section{Strategi Program Kegiatan}

Berdasarkan data hasil survei lapangan dan wawancara serta dengan merujuk pada hasil analisis, maka dapat 
Azwansyah dan Juniardi. "Studi Pengelolaan Infrastruktur Dasar di Kec. Telok Batang" diidentifikasi hal - hal yang menjadi akan dilakukan selanjutnya. Untuk masalah utama dalam desa, sasaran yang identifikasi tersebut dapat dilihat pada ingin dicapai serta program kegiatan yang Tabel 5.

Tabel 5. Matrik Identifikasi Masalah, Sasaran dan Program Kegiatan di Desa Sungai Paduan

\begin{tabular}{|c|c|c|}
\hline LLAHAN & SASARAN & EGIATAN \\
\hline $\begin{array}{l}\text { - Sumber air menggunakan } \\
\text { sungai dan sumur gali dan } \\
\text { tidak layak } \\
\text { - Belum ada pasar tempat } \\
\text { penjualan hasil produksi } \\
\text { pertanian/perkebunan dan } \\
\text { perikanan } \\
\text { - Masih ada penduduk desa } \\
\text { yang belum di alirin listrik } \\
\text { - Belum adanya angkutan } \\
\text { umum yang dapat } \\
\text { menunjang aktifitas } \\
\text { penduduk. prioritas bagi } \\
\text { - Skala pran adalah aspek } \\
\text { penduduk adalan } \\
\text { pertanian/perkebunan }\end{array}$ & 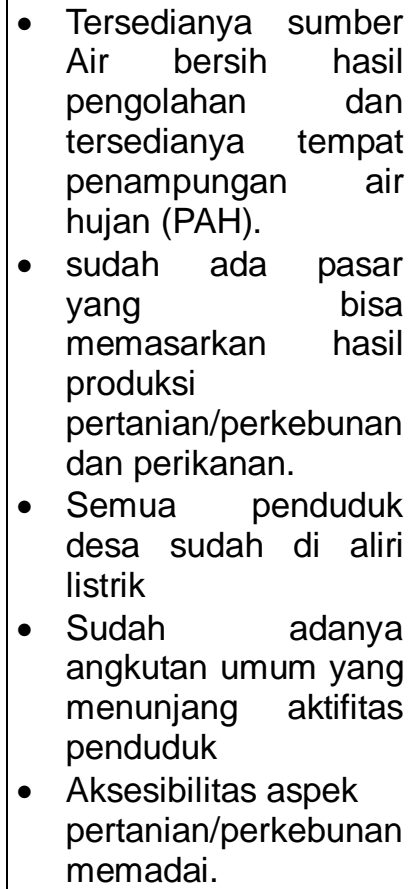 & 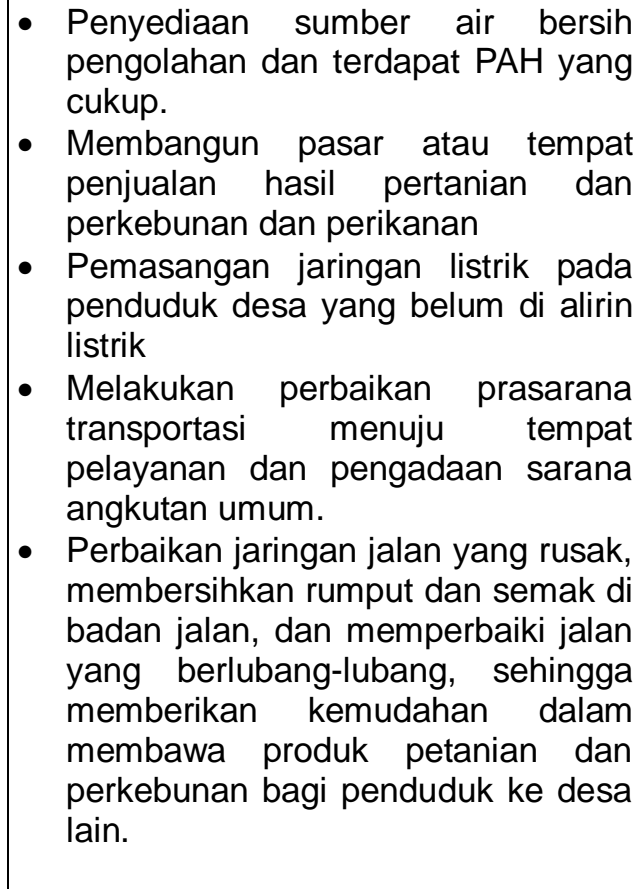 \\
\hline
\end{tabular}

(sumber : Analisis data, 2012)

Tabel 6. Matrik Identifikasi Masalah, Sasaran dan Program Kegiatan di Desa Mas Bangun

\begin{tabular}{|c|c|c|}
\hline & & \\
\hline $\begin{array}{l}\text { - Sumber air menggunakan } \\
\text { sungai dan sumur gali. } \\
\text { - } \text { Belum ada pasar tempat } \\
\text { penjualan hasil produksi } \\
\text { pertanian/perkebunan dan } \\
\text { perikanan } \\
\text { - Masih ada penduduk desa } \\
\text { yang belum di aliri listrik } \\
\text { - Sebagian penduduk desa } \\
\text { kerja nya adalah } \\
\text { nelayan,hasil dari } \\
\text { perikanan biasa jual di } \\
\text { Teluk Batang. dengan jalan } \\
\text { yang rusak, sehingga } \\
\text { mempengaruhi harga jual } \\
\text { Belum adanya angkutan } \\
\text { umum yang dapat } \\
\text { menunjang aktifitas } \\
\text { penduduk. brioritas bagi } \\
\text { Skala adalah aspek } \\
\text { penduduk adah } \\
\text { pertanian/perkebunan }\end{array}$ & 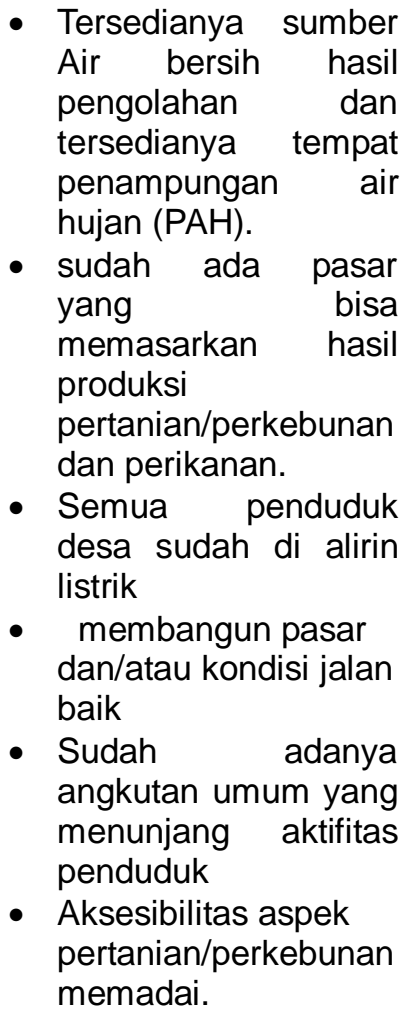 & 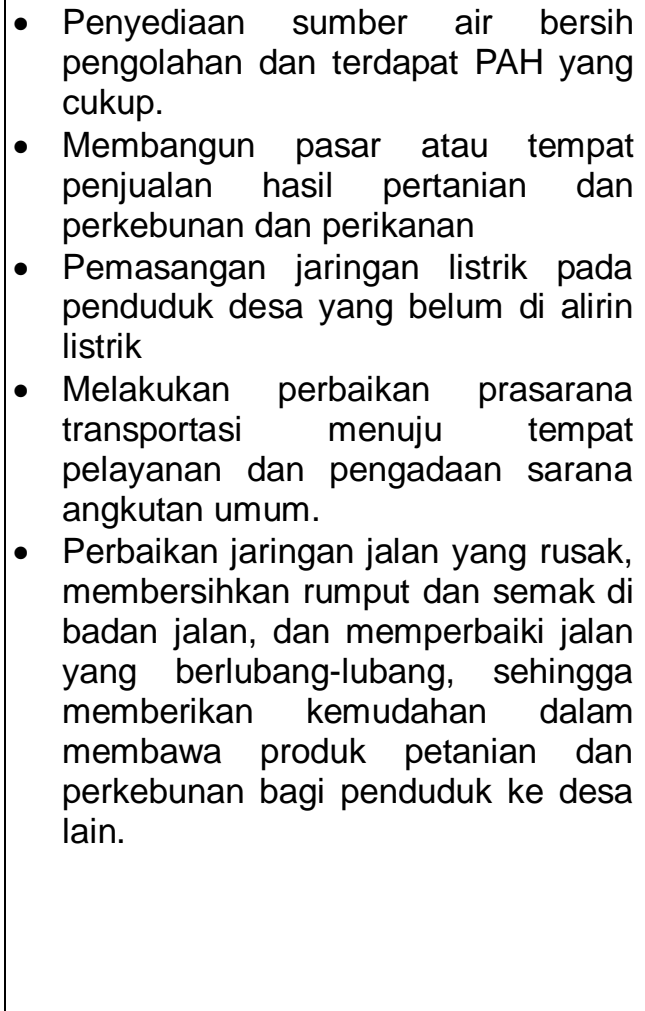 \\
\hline
\end{tabular}

(sumber : Analisis data, 2012) 


\section{Kesimpulan}

- Hasil analisa nilai aksesibilitas yang diprioritaskan pada Kecamatan Teluk Batang sebagai berikut:

- Desa Sungai Paduan nilai aksesibilitas Sektor Pertanian/Perkebunan sebesar 9,90

- Desa Mas Bangun nilai aksesibilitas Sektor Pertanian/Perkebunan sebesar 10,80.

- Priritas utama di Desa Sungai Paduan adalah sektor pertanian/perkebunan, selanjutnya sumber air bersih menempati prioritas kedua dan prioritas ketiga pada industri /perdagangan.

- Desa Mas bangun memiliki prioritas utama kebutuhan infrastruktur adalah di sektor pertanian/perkebunan, selanjutnya sumber air bersih menempati prioritas kedua dan prioritas ketiga pada sektor kesehatan.

- Pendekatan penanganan infrastruktur untuk kedua desa keseluruhan adalah melakukan perbaikan/penyediaan sarana transportasi menuju tempat pelayanan yang dapat menunjang aktivitas penduduk, hal ini dimaksudkan untuk mempermudah mobilitas pergerakan lebih cepat, mudah, dan nyaman.

- Indikator prasarana transportasi (jaringan jalan) tidak menjadi prioritas karena jalan yang ada dirasakan masih bisa melayani pergerakan penduduk desa.

- Beberapa program penyediaan fasilitas yang dapat dilakukan yaitu Penyediaan sumber air bersih pengolahan dan terdapat $\mathrm{PAH}$ yang cukup, membangun pasar atau tempat penjualan hasil pertanian dan perkebunan dan perikanan, pemasangan jaringan listrik pada penduduk desa yang belum di aliri listrik, melakukan perbaikan prasarana transportasi menuju tempat pelayanan dan pengadaan sarana angkutan umum.

\section{Ucapan Terima kasih}

Penulis mengucapkan terima kasih yang sebesar-besarnya kepada pihakpihak yang telah membantu dalam setiap atau sebagian tahapan dari studi ini baik langsung maupun tidak langsung.

\section{Referensi}

Azwansyah, H. 2010. Perencanaan Infrastruktur di Desa Tanjung Satai dan Desa Satai Lestari Kecamatan Pulau Maya Karimata. Jurnal Teknik Sipil Universitas Tanjungpura vol 10 Nomor 2. Desember 2010. Fakultas Teknik Untan. Pontianak.

BPS Kabupaten Kayong Utara. 2012. Kalimantan Barat Dalam Angka, BPS Kabupaten Kayong Utara. Sukadana.

Parikesit, D., Pratama, D.A., Ekawati, N., 2003. Modul Pelatihan Perencanaan Infrastruktur Perdesaan, Kerjasama Universitas Gajah Mada dengan Kementrian Koordonator Bidang Ekonomi dan International Labour Organization. Jurusan Teknik Sipil Fakultas Teknik UGM. Yogyakarta.

Dennis, Ron. 1998. Rural Transport and Accessibility. Development Policies Departement, ILO office Geneva.

Donnges, Chris. 1999. Rural Access and Employment, The Laos Experience. Development Policies Departement, ILO office Geneva.

Komite Pemantauan Pelaksanaan Otonomi Daerah (KPPOD). 2012. Mewujudkan Pembangunan Ekonomi Bagi Kesejahteraan Rakyat. KPPOD Brief Edisi September - Oktober 2012. KPPOD. Jakarta 